José Dinis-Carvalho

Associate Professor

Department of Productions and Systems Engineering School, University of Minho,

Portugal

Luís F. Ferrete

MSc student

Department of Productions and Systems Engineering School, University of Minho,

Portugal

Rui M. Sousa

Assistant Professor Department of Productions and Systems Engineering School University of Minho,

Portugal

Hyggor S. Medeiros

PhD student Department of Productions and Systems Engineering School, University of Minho, Portugal

António J. Magalhães

MSc student Department of Productions and Systems Engineering School, University of Minho, Portugal

João P. Ferreira

MSc student Department of Productions and Systems Engineering School, University of Minho, Portugal

\section{Process Mapping Improvement: Extending Value Stream Maps with Waste Identification Diagrams}

Value Stream Mapping (VSM) is likely the most common tool to represent and analyse the value stream of product families. However, it has several limitations, recognized by professionals and academics, namely in terms of identification of certain types of waste (activities without added value). The purpose of this paper is to present a VSM extension based on elements coming from a new type of representation and analysis tool called Waste Identification Diagram (WID), which is being developed at the Production and Systems Department of University of Minho. WID is able to represent, in an effective manner, information about several aspects, including wastes related with production and people, layout, available capacity and even economic indicators. The inclusion of WID elements within traditional VSM was successfully achieved, resulting in a VSM extension which is more effective than the traditional VSM, not only in the information provided but also in terms of interpretation easiness.

Keywords: Value Stream Mapping; Waste Identification Diagrams, Visual Effectiveness; Economic indicators; Lean Manufacturing.

\section{INTRODUCTION}

In general terms, the clear understanding of the business and production processes is mandatory for any company wishing to diagnose problems and improve performance. Inherent to that requirement, the process mapping tools assume thus a quite important role by providing a representation of processes, which should include relevant pieces of information. The process mapping technique was initially developed by General Electric to help re-engineering teams to achieve an effective understanding of the processes, in the context of the company's "work out" and "best practices" strategy. In fact, the incomplete knowledge about the processes is quite frequent, hindering, or even preventing, the development and implementation of improvement actions. An adequate process mapping should provide companies with important information revealing not only their strengths but mainly their weaknesses, namely the wastes. In the lean manufacturing context are identified seven types of waste: (i) overproduction, (ii) transport (materials), (iii) movement (persons), (iv) defects, (v) inventory, (vi) waiting and (vii) over-processing [1]. Other relevant aspects of production processes should also be included in the processes mapping, e.g. productivity, efficiency,

Received: September 2015, Accepted: November 2015 Correspondence to: Prof. Rui M. Sousa

Departamento de Produção e Sistemas,

Campus de Azurém, 4800-058 Guimarães, Portugal

rms@dps.uminho.pt

doi:10.5937/fmet1504287D

(C) Faculty of Mechanical Engineering, Belgrade. All rights reserved throughput time, etc.

Several tools are available to map processes, e.g. Flowcharts, SIPOC diagrams (Suppliers, Inputs, Process, Outputs, Customers), BPML diagrams (Business Process Modelling Language), VSM (Value Stream Mapping) and WID (Waste Identification Diagrams), but VSM is the most popular. However, VSM has some drawbacks (section 2.1) and thus, to overcome these drawbacks, this work proposes a VSM extension using some elements of the WID diagram that is being developed at the Production and Systems Department of University of Minho. More specifically, two variants of the VSM extension will be presented: (i) the designated "VSM+WID" (section 3.1) and (ii) the "VSM+WIDe" (section 3.2). The second one includes the representation of the economic impact, measured in monetary units (MU), of crucial aspects as work-inprocess $(W I P)$, workforce occupation and transportation effort, while the first one uses the traditional measuring units (quantity, \% and $\mathrm{Kg}^{*} \mathrm{~m}$ ).

As contribution to the validation of the developed work, the new approach was applied to the production process of soda concentrate of a Brazilian company from the beverage sector. A list of criteria is used to assess the potential gains achieved by this extension of VSM based on WID and WIDe.

The paper is organized is 4 sections. After the introduction, section 2 presents a brief literature review about VSM, WID and the fundamentals of the WIDeconomic (WIDe). Section 3 introduces the two variants of the VSM extension based on WID and WIDe and, 
using concrete examples, analyses their effectiveness. Finally, on section 4 the conclusions are outlined.

\section{PROCESS MAPPING TOOLS}

This section briefly presents the VSM (section 2.1) and WID (2.2) as well as the theoretical foundation of WIDe (section 2.3). Regarding VSM and WID, the respective strengths and weaknesses are reported as they will provide part of the context for the proposed extensions of VSM based on some WID features (section 3).

\subsection{Value Stream Mapping}

The Value Stream Mapping (VSM) was developed based on the denominated "Materials and Information Flow Diagram" created by Toyota, and is used to map the value chain of a given product (or family of products), from the suppliers to the client [3]. In general terms, VSM represents the flows of materials and information, allows the quantification of "addedvalue"/"no added value" ratio and the identification of some types of wastes (overproduction and inventory) as well as improvement opportunities. The VSM methodology involves four steps: (i) selection of the product family (eventually using Pareto analysis), (ii) drawing the current state VSM, (iii) drawing the future state VSM and (iv) definition and implementation of the necessary improvement actions.

Despite the referred characteristics, VSM has some limitations as reported by several authors [4], [5], [6], [7], [8], [9] and [10]. More specifically, [10] points out: (i) inability to map different manufacturing routes, (ii) absence of economic indicators, (iii) absence of layout representation and (iv) does not reflect the bill-ofmaterials (BOM). According to [11] and [12] the transportation waste is not quantified and [11] additionally stated that waiting, over-processing and motion wastes are difficult to observe, remaining virtually "hidden" on the VSM. Lastly, VSM does not represent the wastes related to people.

A recent work involving a VSM extension can be found in [13], where it is described an extension of value stream mapping through waste identification beyond the clients' perspective. However, this approach was specifically created to analyse software development processes being thus applicable only in that context. In [14] it is described a new framework to apply VSM to production scenarios involving families of products with multiple routes and complex bill-ofmaterials. This framework does not improve the waste identification capabilities of the traditional VSM.

\subsection{Waste Identification Diagram}

The Waste Identification Diagram (WID) is a representation tool for production units, specifically developed to overcome some of the VSM limitations, namely in terms of wastes representation [2]. In fact, WID is able to represent wastes related to materials (inventory, overproduction, transport and defects) as well as wastes related to people (motion, transport, waiting and over-processing). Additionally, an innovative characteristic of WID is the use of the physical dimensions of its symbols to transmit, in an immediate an effective way, important information about the production process (e.g. WIP, transportation effort, setup time and idle time).

The WID is a network of tri-dimensional blocks and bidimensional arrows and there are two types of blocks: the basic version and the advanced version; the last includes OEE (Overall Equipment Effectiveness) information. In the basic version (Figure 1), each block represents a process, or a group of processes, and its dimensions are used to represent: (i) Takt time $\left(T_{T}\right)$ and Cycle time $\left(T_{C}\right)$, (ii) Workin-process $(W I P)$ and (iii) Setup time $\left(T_{S}\right)$.

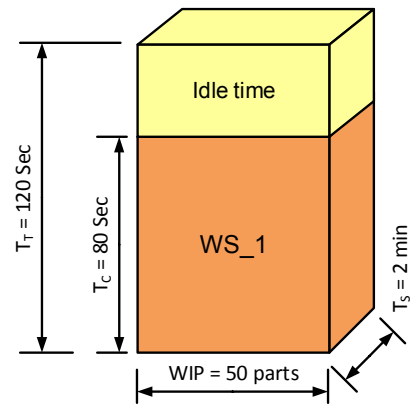

Figure 1. WID symbol: process block (basic version)

In the advanced version (Figure 2), each block includes OEE information related to availability, performance (or speed) and quality losses. $S_{T T}$ and $U_{T T}$ are the standard takt time and useful takt time, respectively.

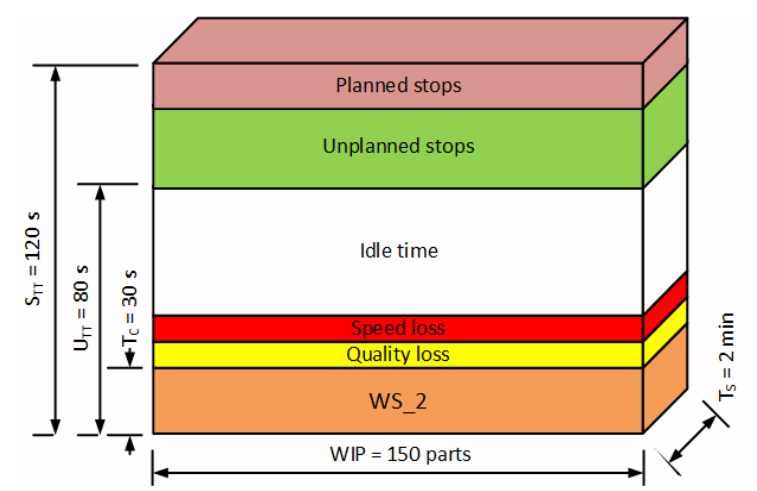

Figure 2. WID symbol: process block (advanced version)

The arrows (Figure 3) represent the transportation of materials between processes (blocks) and its width is proportional to the transportation effort $E_{T}$ (e.g. measured in $\mathrm{Kg}^{*} m$ or $\left.\operatorname{part}^{*} m\right)$. A circular graph depicts the workforce occupation (Figure 3).
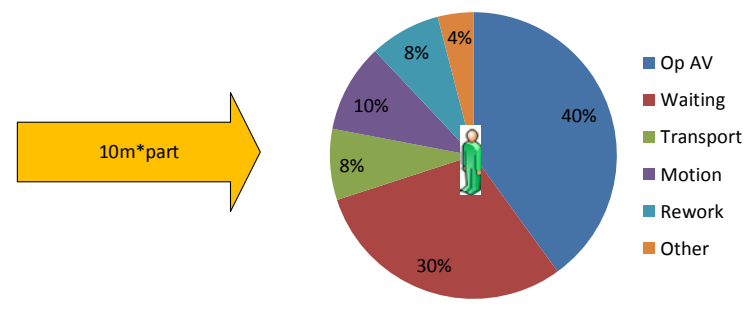

Figure 3. WID symbols: Transportation effort arrow and workforce occupation circular graph

The data on the circular graph is based on a number of samples (observations in the shop-floor) conducted at 
several moments of the working day and using a predefined path, accordingly to the WID methodology described in [2].

By observing the dimensions of the blocks on the examples of Figure 1 and Figure 2, it is immediately perceived that workstation 2 (WS_2) has much more WIP than workstation 1 (WS_1). It is also evident the larger unused capacity of WS_ 2 . Furthermore, the larger frontal area of WS_2 block indicates a larger throughput time (according to Little's law [15]). Thus, even without reading the values on WID, it is possible to visually obtain important pieces of information just by looking to the physical dimensions of the WID blocks. In fact, that also happens with the transportation arrow (Figure 3) - the thicker the arrow, the higher the transportation effort. In a lean management context, companies should reduce the transportation waste, making this arrow as thinnest as possible.

Additional features of WID include the ability to represent the layout of the production unit and, as already referred, the inclusion of OEE information [16]. $\mathrm{OEE}$ is an indicator of the effectiveness of equipment utilization. In fact, in practice, and due to different types of losses, there is no equipment that runs always at its required rate and makes only good products. So, the identification of the causes of these losses is mandatory to improve the equipment's OEE. Accordingly, there have been identified three main losses: availability, performance and quality losses; which were further subdivided and denominated as the "six big losses" to determine which area should be improved. In the availability loss are involved planned downtimes and breakdowns, in performance loss are included minor stops and speed losses and quality loss include the defects during start-up and steady production. The WID blocks show these OEE components by dividing the blocks using different colours for: planned and unplanned stops (availability), speed losses (performance) and quality losses (Figure 2).

The most recognized WID limitation is the inability to represent the information flow, which is one of the advantages of VSM.

\subsection{Waste Identification Diagram - economic}

The Waste Identification Diagram - economic (WIDe) is a WID where some values are represented using monetary units. The WIDe uses an approach based on direct costs (raw materials and labour) associated to the product costing function. The direct cost is basically the cost directly linked to the cost object and can be easily traced [17], [18].

From the economic perspective, the WIDe describes the information contained in the process blocks, transportation arrows and workforce occupation circular graph (Figure 3), as: economic takt time $\left(T_{T e}\right)$, economic cycle time $\left(T_{C e}\right)$, cost of work-in-process $\left(C_{W I P}\right)$, cost of setup $\left(C_{S}\right)$, cost of transportation $\left(C_{T}\right)$ and cost of workforce waste $\left(C_{W W}\right)$.

The $T_{T e}$ is based on the concept of $T_{T}$ but, instead of representing the rate at which the market demands one unit of product, it represents the rate at which the market demands one monetary unit. Thus, $T_{T e}$ suggests that the market consumes monetary units of the production process in order to fulfil the demand for manufacturing one unit of product. $T_{T e}$ is given by:

$$
T_{T e}=\frac{T_{T}}{C_{R M}} .
$$

where:

$$
\begin{array}{ll}
T_{T} & \text { takt time, } \\
C_{R M} & \text { raw materials cost (per product). }
\end{array}
$$

However, notice that each workstation has its own $T_{T e}$ depending on the cost of the product (raw materials) after being processed by that workstation, i.e.:

$$
T_{T e, i}=\frac{T_{T}}{C_{R M o u t, i}} .
$$

where:

$$
\begin{array}{ll}
T_{T} & \text { takt time, } \\
C_{R M o u t, i} & \text { raw materials cost (workstation } i \text { exit), } \\
i & \text { workstation identification number. }
\end{array}
$$

The concept of economic takt time $\left(T_{T e}\right)$ presents another way of seeing the market's demand, proposing the use of the cost of the raw material as a base for other interpretations (e.g. involving workstations and transportation) within the production unit. This proposal is aligned with the Goldratt's perspective that differs from the traditional approaches by considering that, in economic terms, the inventory corresponds to "all the money that systems invests in purchasing things that it intends to sell... it excludes the added value of labour and overhead" [19]. Accordingly, for a given workstation $i$, while $T_{C}$ represents the cycle time in terms of a product unit, the $T_{C e}$ represents the cycle time in terms of a monetary unit. In other words, $T_{C e, i}$ shows the time necessary to workstation $i$ process one monetary unit and is given by:

$$
T_{C e, i}=\frac{T_{C, i}}{C_{\text {RMout }, i}} .
$$

where:

$$
\begin{array}{ll}
T_{C, i} & \text { cycle time (workstation } i \text { ), } \\
C_{R M o u t, i} & \text { raw materials cost (workstation } i \text { exit), } \\
i & \text { workstation identification number. }
\end{array}
$$

The cost of work-in-process in a workstation $i\left(C_{W I P, i}\right)$ corresponds to the monetary value of the raw materials waiting to be processed on that workstation, and therefore:

$$
C_{W I P, i}=W I P_{i} \times C_{R M i n, i} .
$$

where:

$$
\begin{array}{ll}
W I P_{i} & \text { work-in-process (workstation } i \text { ), } \\
C_{R M i n} & \text { raw materials cost (workstation } i \text { entry), } \\
i & \text { workstation identification number. }
\end{array}
$$

Note that on WIDe it is important to distinguish between the cost of the product (raw materials) at the workstation entry $\left(C_{R M i n, i}\right)$ and the cost of the product (raw materials) after being processed by that workstation $\left(C_{R M o u t, i}\right)$.

For workstation $i$, the setup $\operatorname{cost}\left(C_{S, i}\right)$ is given by:

$$
C_{S, i}=T_{S, i} \times C_{S U, i} \text {. }
$$

where: 


$$
\begin{array}{ll}
T_{S, i} & \text { setup time (workstation } i \text { ), } \\
C_{S U, i} & \text { setup unitary cost (workstation } i \text { ), } \\
i & \text { workstation identification number. }
\end{array}
$$

Figure 4 depicts an example of the WIDe block symbol (basic version), with concrete values assigned to the previously referred data items: economic takt time $\left(T_{T e}\right)$, economic cycle time $\left(T_{C e}\right)$, WIP cost $\left(C_{W I P}\right)$ and setup $\operatorname{cost}\left(C_{S}\right)$

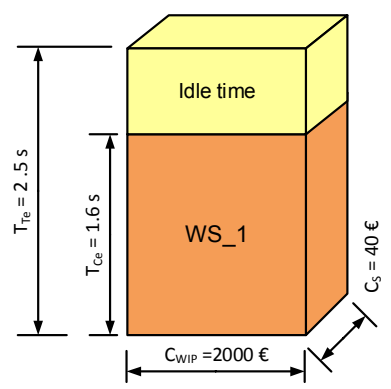

Figure 4. WIDe symbol: block (basic version)

The transportation cost between two locations $i$ and $j$ $\left(C_{T, i, j}\right)$, represents the monetary value associated to the transportation effort $\left(E_{T, i, j}\right)$ between these locations and is obtained from:

$$
C_{T, i, j}=E_{T, i, j} \times C_{T U, i, j} .
$$

where:

$$
\begin{array}{ll}
E_{T, i, j} & \text { transportation effort (between } i \text { and j) } \\
C_{T U, i, j} & \text { transport. unitary cost (amongst } i \text { and } j \text { ), } \\
i, j & \text { locations identification numbers. }
\end{array}
$$

Regarding the time periods corresponding to planned and unplanned stops, idle capacity and speed loss (in each workstation), as they are represented per product, their conversion to the "economic versions" is based on the same approach used with $T_{T e, i}$ and $T_{C e, i}$.

Figure 5 represents an example of the WIDe transportation cost arrow. In this case the transportation effort occurs between locations 1 and 2 and has a cost of $4000 €$. Naturally, as with WID, the thicker the arrow, the higher the transportation cost.

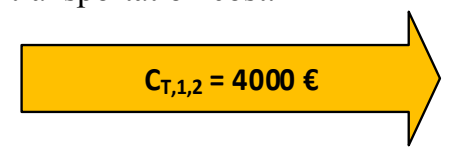

\section{Figure 5. WIDe symbol: Transportation cost arrow}

The total cost of transportation $\left(C_{T}\right)$ is given by the sum of the partial transportation costs $C_{T, i, j}$. The total cost of the wastes associated to the workforce occupation $\left(C_{W W}\right)$, are given by:

$$
C_{W W}=P_{W W} \times C_{W U} \times n .
$$

where:

$$
\begin{array}{ll}
P_{W W} & \text { workforce waste percentage, } \\
C_{W U} & \text { workforce unitary cost, } \\
n & \text { number of workers. }
\end{array}
$$

The costs inherent to a given kind of workforce occupation (added-value operation, waiting, transport, motion, rework and other) are calculated using equation (7), by substituting $P_{W W}$ by the workforce occupation percentage corresponding to that type of occupation.

\section{VSM EXTENSIONS}

This section presents the two extensions of VSM proposed in this work: VSM+WID and VSM+WIDe, along with the corresponding analysis in terms of representation capacity.

\subsection{Extension of VSM with WID}

In order to improve the effectiveness of VSM it is proposed the integration of some WID features into the VSM diagrams.

As simple example, Figure 6 depicts the mapping of the production process of soda concentrate in a Brazilian company (operating 2 shifts with 7 hours each), where the WID blocks and transportation effort arrows are embedded in a VSM diagram.

As can be observed in Figure 6, this integration keeps the essence of VSM, which is the representation of the material and information flows across the entire process, while incorporating some valuable WID features, namely the meaningful interpretation of the physical dimensions of WID symbols. In fact, the block dimensions allow an immediate perception, for each workstation, of WIP, cycle time, setup time and throughput time, even without reading the corresponding values. For example (Figure 6), clearly, the mixing workstation is the process bottleneck (highest cycle time) with the larger WIP (widest block) and throughput time (block with the largest frontal area). Similarly, the weigh workstation has the highest available capacity (largest idle time) and the highest transportation effort (thicker arrow) occurs between the warehouse and the mixing workstation.

Another evident improvement with respect to VSM is the inclusion of a circular graph that represents the information about how the workers occupy their time.

The comparison of the VSM+WID map with VSM and WID, in terms of representation features, can be observed on Table 1.

Table 1. Comparison of representation capacity

\begin{tabular}{|l|c|c|c|}
\hline Representation capacity & VSM & WID & VSM+WID \\
\hline Information flow & Yes & No & Yes \\
\hline Production flow & Yes & Yes & Yes \\
\hline Overproduction waste & Yes & Yes & Yes \\
\hline Inventory waste & Yes & Yes & Yes \\
\hline Transportation waste & No & Yes & Yes \\
\hline People related wastes & No & Yes & Yes \\
\hline OEE information & No & Yes & Yes \\
\hline Dimensional meaning & No & Yes & Yes \\
\hline Multiple routes & No & Yes & No \\
\hline Layout representation & No & Yes & No \\
\hline
\end{tabular}

Table 1 shows that the extension of VSM with WID covers some of the limitations of VSM, namely its inability to represent transportation waste, waste related to people utilization and OEE information.

Additionally, the VSM+WID inherits the distinctive characteristic of WID: the designated "dimensional meaning" (i.e. the meaning of the physical dimensions of the block and transportation arrow symbols). 


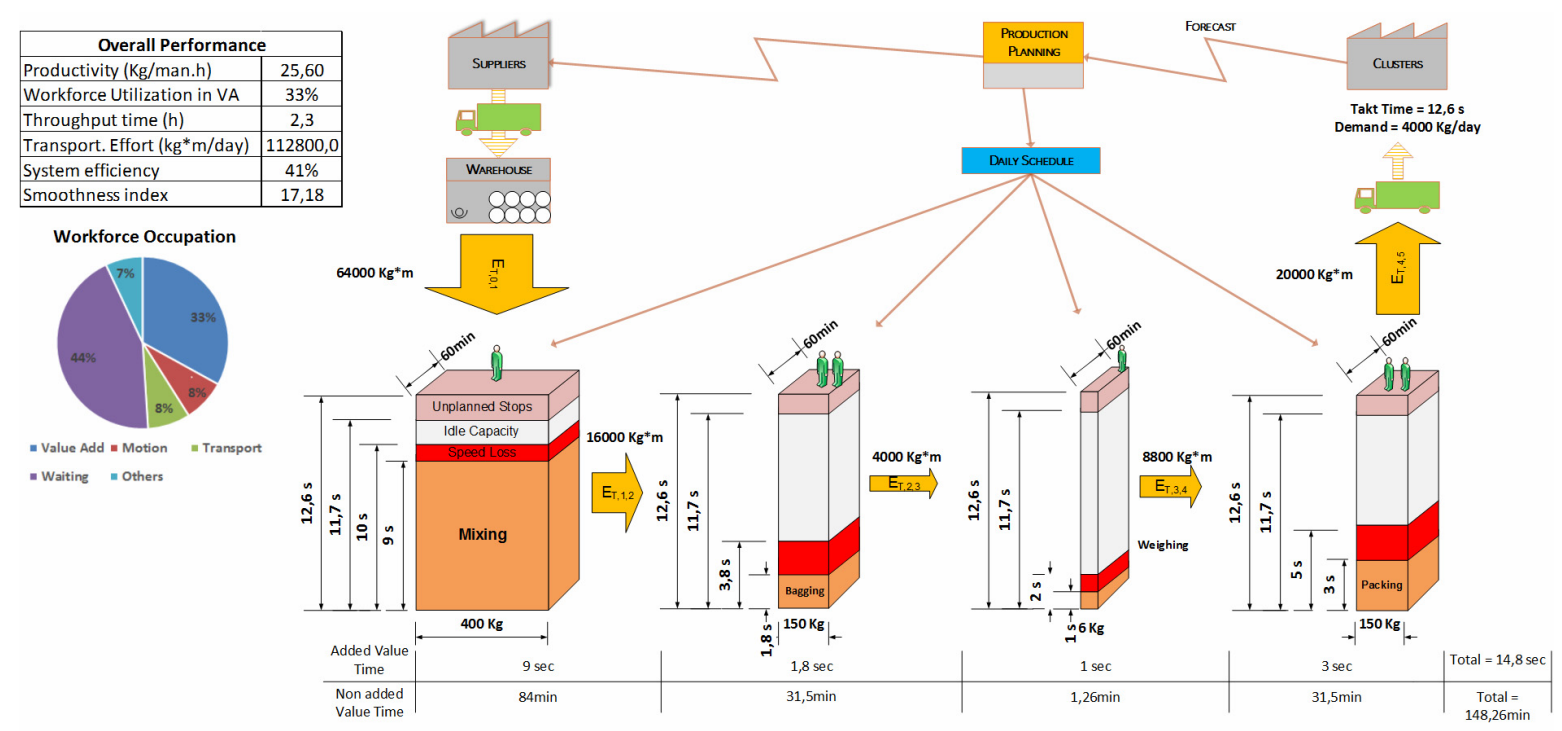

\section{Figure 6. Extension VSM+WID}

\subsection{Extension of VSM with WIDe}

In order to enhance VSM with the inclusion of relevant economic figures, it is proposed the VSM+WIDe extension. Hence, the construction of this kind of map implies the gathering of economic data, namely, raw material costs, setup costs and workers' payroll. The example in the previous section will be used here and, as currency, it is adopted the concept of monetary unit (MU). Table 2 presents the involved costs.

\section{Table 2. Costs}

\begin{tabular}{|l|c|}
\hline Designation & Cost \\
\hline Worker payroll & $750 \mathrm{MU} / \mathrm{man} . \mathrm{month}$ \\
\hline Unitary cost of setup & $110 \mathrm{MU} / \mathrm{h}$ \\
\hline Unitary cost of transportation & $0.1 \mathrm{MU} / \mathrm{Kg} . \mathrm{m}$ \\
\hline Main raw mat. (A) cost (mixing) & $30 \mathrm{MU} / \mathrm{Kg}$ \\
\hline Raw material B cost (mixing) & $10 \mathrm{MU} / \mathrm{Kg}$ \\
\hline Raw material C cost (bagging) & $0.25 \mathrm{MU} / \mathrm{Kg}$ \\
\hline Raw material D cost (packing) & $1 \mathrm{MU} / \mathrm{Kg}$ \\
\hline Total raw material cost & $41.25 \mathrm{MU} / \mathrm{Kg}$ \\
\hline
\end{tabular}

Based on the values indicated on Table 2 as well as on information from the VSM+WID represented in Figure 6, the necessary VSM+WIDe (Figure 7) indicators can be calculated. Thus, according to (1) the economic takt time is:

$$
T_{T e}=\frac{T_{T}}{C_{R M}}=\frac{12.6}{41.25}=0.305 \mathrm{~s} .
$$

This means that the market demands one MU every 0,305 seconds. Regarding the cost of product (raw materials cost), Table 3 contains the values before and after each workstation, i.e. $C_{R M i n, i}$ and $C_{R M o u t, i}$ respectively.

Table 3. Product cost before and after processing

\begin{tabular}{|l|c|c|}
\hline Workstation & $\mathrm{C}_{\mathrm{RMin}, \mathrm{i}}[\mathrm{MU} / \mathrm{Kg}]$ & $\mathrm{C}_{\mathrm{RMout}, \mathrm{i}}[\mathrm{MU} / \mathrm{Kg}]$ \\
\hline 1. Mixing & 30 & 40 \\
\hline 2. Bagging & 40 & 40.25 \\
\hline 3. Weighing & 40.25 & 40.25 \\
\hline 4. Packing & 40.25 & 41.25 \\
\hline
\end{tabular}

The product cost of $30 \mathrm{MU} / \mathrm{Kg}$ at the entry of the mixing workstation $\left(C_{R M i n, 1}\right)$ is given by the cost of the main raw material (Table 2). As the mixing incorporates the raw material $\mathrm{B}$, the cost of the product rises to 40 $\mathrm{MU} / \mathrm{Kg}$. Naturally, the product cost at the packing exit $\left(C_{R M o u t, 4}\right)$ equals the cost of the final product $\left(C_{M R}\right)$.

The economic takt time $\left(T_{T e, i}\right)$ and the economic cycle time $\left(T_{C e, i}\right)$ of each workstation are presented on Table 4. It is important to understand that $T_{T e, i}$ is associated to the demand of a monetary unit, placed by the market to workstation $i$, and, because the cost of the product at the workstation exit depends on the incorporated raw materials, the $T_{T e, i}$ varies depending on the workstation.

Table 4. $T_{T e}$ and $T_{C e}$ of each workstation

\begin{tabular}{|c|c|c|c|}
\hline Workstation & $\mathrm{T}_{\mathrm{Te}, \mathrm{i}}[\mathrm{s}]$ & $\mathrm{T}_{\mathrm{Ce}, \mathrm{i}}[\mathrm{s}]$ & Equation \\
\hline 1. Mixing & 0,315 & 0.225 & \multirow{4}{*}{$(2,3)$} \\
\hline 2. Bagging & 0,313 & 0.045 & \\
\hline 3. Weighing & 0,313 & 0.025 & \\
\hline 4. Packing & 0,305 & 0.073 & \\
\hline
\end{tabular}

Note that the economic takt time in the packing workstation, equals the economic takt time (8) and also that $T_{T e, 3}$ equals $T_{T e, 2}$ because the weighing workstation does not add any raw material.

In terms of WIP cost (cost of raw materials) and setup cost (per setup) inherent to each workstation, i.e. $C_{W I P, i}$ and $C_{S, i}$, respectively, the values are presented in Table 5.

Table 5. $C_{\text {WIP }}$ and $C_{s}$ of each workstations

\begin{tabular}{|c|c|c|c|}
\hline Workstation & $\mathrm{C}_{\mathrm{WIP}, \mathrm{i}}[\mathrm{MU}]$ & $\mathrm{C}_{\mathrm{S}, \mathrm{i}}[\mathrm{MU}]$ & Equation \\
\hline 1. Mixing & 12000 & $110 \mathrm{MU}$ & \multirow{4}{*}{$(4,5)$} \\
\hline 2. Bagging & 6000 & $110 \mathrm{MU}$ & \\
\hline 3. Weighing & 241.5 & $110 \mathrm{MU}$ & \\
\hline 4. Packing & 6037.5 & $110 \mathrm{MU}$ & \\
\hline
\end{tabular}

Regarding the transportation cost between locations $i$ and $j$, i.e. $C_{T, i, j}$, the necessary data is on Table 2 (unitary cost of setup) and on the WID+VSM map of Figure 6 (transportation effort). The values are presented on Table 6. 


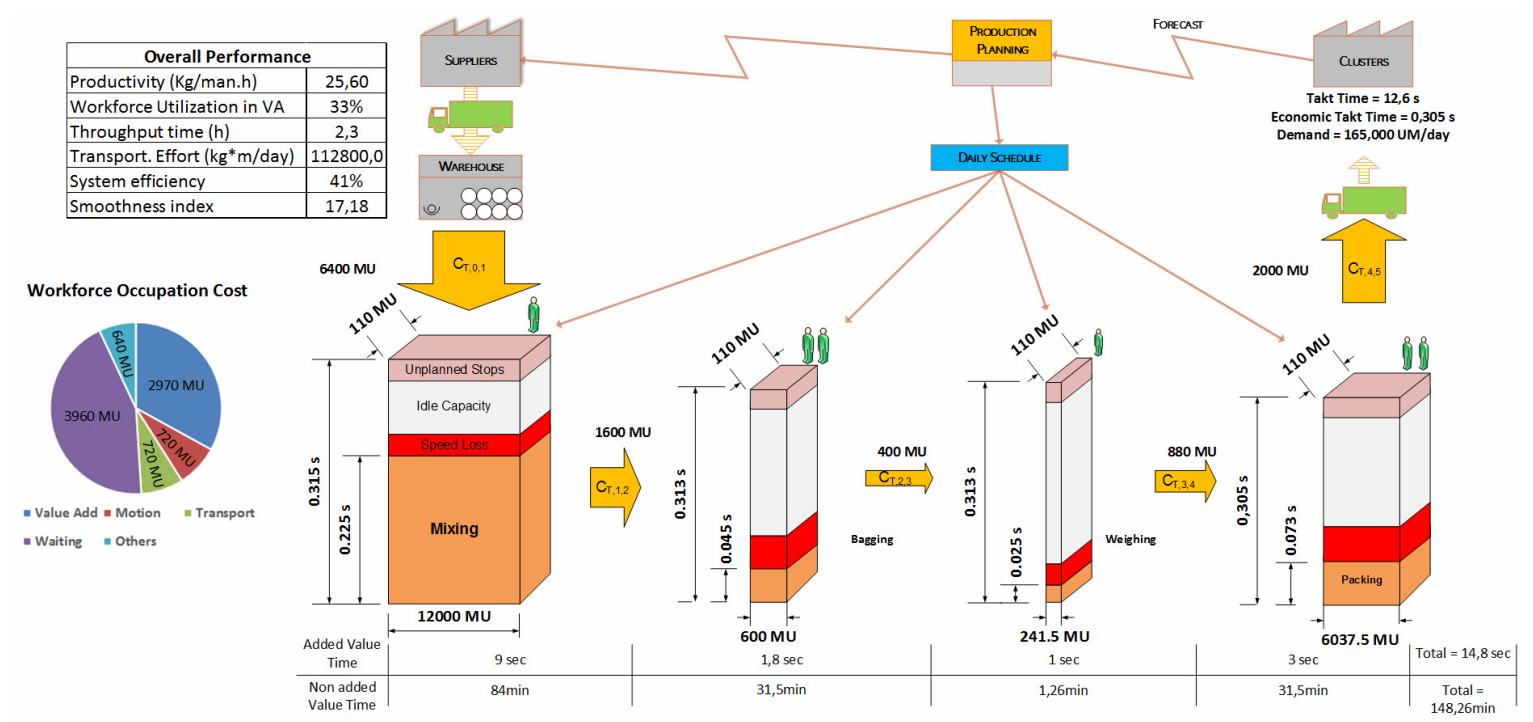

Figure 7. Extension VSM+WIDe

Table 6. Transportation cost between locations

\begin{tabular}{|l|c|c|}
\hline Transportation & $\mathrm{C}_{\mathrm{T}, \mathrm{i}, \mathrm{j}}[\mathrm{MU}]$ & Equation \\
\hline 0. Warehouse - 1. Mixing & 6400 & \multirow{2}{*}{ (6) } \\
\cline { 1 - 2 } 1. Mixing - 2. Bagging & 1600 & \multirow{2}{*}{ 2. Bagging - 3. Weighing } \\
\cline { 1 - 2 } 3. Weighing - 4. Packing & 800 & \\
\cline { 1 - 2 } 4. Packing - 5. Customer & 2000 & \\
\hline
\end{tabular}

Lastly, the calculation of the cost inherent to the workforce occupation is based on the workers payroll (Table 2) and on the circular graph included in the

VSM+WID map (Figure 6). The total cost of the wastes related to workforce occupation, i.e. $C_{W W}(6)$, is:

$$
C_{W W}=P_{W W} \times C_{W U} \times n=067 \times 750 \times 12=6030 M U
$$

Recall that the working day has 2 shifts, each one with 6 workers. The partial costs associated to the different types of occupation are included in Table 7.

\section{Table 7. Workforce occupation costs}

\begin{tabular}{|l|c|c|}
\hline Workforce occupation & Cost [MU] & Total [MU] \\
\hline Added-value operation & 2970 & 2970 \\
\hline Waiting & 3960 & \multirow{2}{*}{6030} \\
\cline { 1 - 2 } Transport & 720 & \\
\cline { 1 - 2 } Motion & 720 & \\
\cline { 1 - 2 } Other & 630 & \\
\hline
\end{tabular}

Based on the calculated data, the VSM+WIDe map was constructed, being depicted on Figure 7.

The same aspects already identified in the VSM+WID extension can now be interpreted in monetary terms.

As can be observed, the highest WIP cost occurs on the mixing workstation, followed by the packing workstation. On the VSM+WID map (Figure 6) the blocks representing the bagging and the packing workstations have the same width $\left(W I P_{2}=W I P_{4}=\right.$ $150 \mathrm{Kg}$ ). However, the VSM+WIDe map (Figure 7) clearly shows that the cost of that quantity of WIP is higher on the packing workstation (due to the higher cost of raw materials at its exit). Obviously, a small quantity of WIP (narrow block on VSM+WID map) may imply a high inventory cost (wide block on VSM+WIDe).

From the frontal area of the blocks it is immediately perceived that the mixing workstation is the place where one MU spends more time (throughput time).

The highest transportation cost occurs between the warehouse and the mixing workstation and the circular graph represents now the costs associated to workforce occupation. As can be observed, the waiting time of the workforce represents a monthly cost of 3960 MU, surpassing thus the cost associated to added-value activities (2970 MU).

The setup cost is $110 \mathrm{MU}$ in every workstation because in this case the setup unitary cost is always the same $(110 \mathrm{UM} / \mathrm{h})$, regardless the involved workstation.

\section{CONCLUSION}

This work successfully introduced an extension of the well-known Value Stream Mapping (VSM) in order to overcome some of its limitations, especially in terms of ability to represent wastes (activities without added value) and economic indicators.

The extension was achieved by including on VSM some features of the designated Waste Identification Diagram (WID), a representation tool developed in the Production and Systems Department of University of Minho, Portugal. As WID (section 2.2) has also an economic version, named WIDe (section 2.3), in fact, two variants of the VSM extension were developed: the VSM+WID map (section 3.1) and the VSM+WIDe map (section 3.2).

Both variants inherit a distinctive characteristic of WID (and WIDe) which is the dimensional meaning of its symbols, allowing an immediate perception of important aspects of the represented production unit, even without reading the values on the map. The easy perception, through the simple observation of the dimensions of the symbols, include the identification of the workstation with the highest: (i) throughput time (per product or monetary unit), (ii) setup time, (iii) setup cost, (iv) available capacity, (v) WIP (quantity or 
monetary cost), (vi) OEE losses, etc. Similarly, a quick glance to a VSM+WID map allows the immediate identification of the point where the highest transportation effort occurs and, in the case of the VSM+WIDe map, also the corresponding cost.

Regarding the identification of waste related to people (waiting, transport, motion and rework), the circular graph representing the workforce occupation expressed in percentage was inherited from the WID or from the WIDe when expressed as cost. Thus, an important limitation of VSM was overcome.

Despite the acquired advantages, the VSM+WID and VSM+WIDe maps neither represent the production units' layout nor production units with multiple routes (these are distinctive features of WID and WIDe).

An adequate representation of a production unit is a crucial task not only to formalize the current state of the production processes, but especially to identify the main problems and, consequently, the corresponding improvement opportunities. Power of representation and ease of interpretation are mandatory characteristics for any representation tool wishing to play a relevant role in the industrial engineering area.

Accordingly, the authors consider that the developed VSM extensions bring concrete benefits to the issue of representation of production units, namely the dimensional meaning and the representation of people related waste, constituting thus effective communication tools between analysts and workers.

In terms of future work, new developments are being studied, mainly in the WIDe context.

\section{REFERENCES}

[1] Ohno, T.: Toyota Production System: Beyond large-scale production, Productivity Press, Portland, Oregon, 1988.

[2] Dinis-Carvalho, J., Moreira, F., Bragança, S., Costa, E., Alves, A. and Sousa, R.: Waste Identification Diagram, Production Planning \& Control, The Management of Operations, Published online: 24 Mar 2014.

[3] Rother M. and Shook, J.: Learning to see - value stream mapping to create value and eliminating muda, 1.2 ed. Brookline: The Lean Enterprise Institute, 1999.

[4] Lian, Y. H. and van Landeghem, H.: Analysing the effects of Lean manufacturing using a value stream mapping-based simulation generator, International Journal of Production Research, Vol. 45, No. 13, pp. 3037-3058, 2007.

[5] Serrano, I., Ochoa, C. and De Castro, R.: Evaluation of value stream mapping in manufacturing system redesign, International Journal of Production Research, Vol. 46, No. 16, pp. 4409-4430, 2008.

[6] Xinyu, L. and Jian, L.: Research on the Integration of the Methods of Enterprise Value Stream and Material Flow, in Proc. of the IEEE 16th International Conference on Industrial Engineering and Engineering Management, 2009, Beijing, China.
[7] Kemper, B., de Mast, J. and Mandjes, M.: Modeling Process Flow Using Diagrams, Quality and Reliability Engineering International, Vol. 26, No. 4, pp. 341-349, 2010.

[8] Singh, B., Garg, S. K. and Sharma, S. K.: Value stream mapping: literature review and implications for Indian industry, International Journal of Advanced Manufacturing Technology, Vol. 53, No. 5-8, pp. 799-809, 2011.

[9] Teichgraber, U. K. and Bucourt, M.: Applying value stream mapping techniques to eliminate nonvalue-added waste for the procurement of endovascular stents, European Journal of Radiology, Vol. 81, 2012.

[10] Irani, S. A. and Zhou, J.: Value Stream Mapping of a Complete Product, MS thesis, The Ohio State University, Columbus, OH, 1999.

[11]Lovelle, J.: Mapping the value stream, IIE Solutions, Vol. 33, No. 2, pp. 26-33, 2001.

[12]Huang, C. C. and Liu, S H.: A novel approach to lean control for Taiwan-funded enterprises in mainland China. International Journal of Production Research, Vol. 43, No. 12, pp. 25532575, 2005.

[13]Khurum, M., Petersen, K. and Gorschek, T.: Extending value stream mapping through waste definition beyond customer perspective, Journal of Software: Evolution and Process, Vol. 26, No. 12, pp. 1074-1105, 2014.

[14] M. Braglia, M., Carmignani, G. and Zammori, F.: A new value stream mapping approach for complex production systems, International Journal of Production Research, Vol. 44, No. 18-19, pp. 3929-3952, 2006.

[15] Little, J.: A proof for the queuing formula: $L=\lambda \mathrm{W}$, Operations Research, Vol. 9, pp. 383-389, 1961.

[16] Dinis-Carvalho, J., Guimarães, L., Moreira, F., Rodrigues, J. and Lima, R. M.: Waste Identification Diagrams with OEE data, in Proceedings of the CIO-ICIEOM-IIIE 2014, July 23-25, Malaga Spain, ISBN-13978-84-616-9935-3, pp. 313-320, 2014.

[17]Blocher, E. J., Stout, D. E. and Cokins, G.: Cost Management: a strategic emphasis (5th ed.), New York: Mcgraw-Hill, 2010.

[18]Hansen, D. R., Mowen, M. M. and Guan, L.: Cost management accounting \& control (6th ed.), Mason: South-Western Cengage Learning, 2009.

[19] Goldratt, E. M. and Fox, R. E.: The Race, North River Press, New-York, 1986.

\section{УНАПРЕЪЕЊЕ ПРОЦЕСА МАПИРАЊА: ПРОШИРЕНА МАПА ТОКА ВРЕДНОСТИ СА ДИЈАГРАМИМА ЗА УТВРЪИВАЊЕ ГУБИТАКА}

Ж. Диниш-Карваљо, Л. Ф. Феррете, Р. М. Соуза, Е. С. Медеируш, А. Ж. Магаљаеш, Ж. П. Ферреира 
Мапирање тока вредности је алат који се вероватно најчешће користи за приказивање и анализу тока вредности фамилија производа. Међутим, овај алат има својих ограничења, која потврђују и професионалци и истраживачи, у погледу утврђивања одређених типова губитака (активности без додате вредности). Циљ овога рада јесте да прикаже проширено мапирање тока вредности помоћу елемената новог алата за приказивање и анализу: Дијаграма за утврђивање губитака, који је развијен на Одсеку за производњу и системе
Универзитета у Мињу. Нови алат може да пружи поуздане информације о неколико елемената: губитке везане за производњу, људе, план, распоред опреме, па чак и економске показатеље. Укључивање елемената дијаграма за одређивање губитака у класично мапирање тока вредности успешно је остварено, резултујући у проширену мапу тока вредности која је много ефиктивнија од постојеће, не само у погледу добијених информација већ и у погледу једноставности њиховог тумачења. 